\title{
Production, Characterization and Evaluation of Bacterial Protease as a Potential Additive to Enhance Detergency of Endod
}

\author{
Rahel Tilahun \\ School of Graduate Studies, Microbial, Cellular, and Molecular Biology Department, Addis Ababa University, Addis Ababa, Ethiopia \\ Email address: \\ raheltilahun01@gmail.com \\ To cite this article: \\ Rahel Tilahun. Production, Characterization and Evaluation of Bacterial Protease as a Potential Additive to Enhance Detergency of Endod. \\ International Journal of Microbiology and Biotechnology. Vol. 5, No. 4, 2020, pp. 193-202. doi: 10.11648/j.ijmb.20200504.14
}

Received: November 19, 2020; Accepted: December 3, 2020; Published: December 16, 2020

\begin{abstract}
At present alkaline proteases are widely used in the detergent, leather tanning, pharmaceutical, food, and feed processing industries. Although proteases are found in all living organisms (plant, animal, and microorganisms), the bulk of commercially important enzymes are from microorganisms. The aim of this study was to isolate protease producing bacteria, characterize the enzyme, and evaluate potential application as detergent additive to enhance the washing performance of endod berries. Different bacterial strains were isolated from soil and screened using an alkaline casein agar media. One isolate designated as aau 2106 was selected for further study because of its high proteoliytic activity, level of enzyme production and, ability to grow under solid state fermentation (SSF). Cultivation condition for the production of the enzyme under SSF, such as, moisture content, nitrogen content, and incubation period were optimized. The enzyme was active in the $\mathrm{pH}$ range of 6 to 10.5 , temperature of 40 to $75^{\circ} \mathrm{C}$. And optimum in; $96 \mathrm{~h}$ incubation period, 1:1 ratio of moisture content and, casein in the production of enzyme under SSF and the enzyme was stable in the presence of endod and commercial detergents. The potential of the enzyme as a detergent additive was tested by adding the protease $(57 \mathrm{U} / \mathrm{g})$ in detergent formulations and used to clean pieces of cloth stained with blood and egg. Addition of the enzyme improved the cleaning efficiency of both endod and commercial detergents. This indicates that enzyme supplementation of endod could result in the development of an ecofriendly detergent.
\end{abstract}

Keywords: Detergent, Endod, Protease

\section{Introduction}

Proteases are enzymes that hydrolyse proteins by breaking down the peptide bonds via the addition of water resulting in the formation of peptide fragments (Figure 1) [1].

Proteases derived from microorganisms, animals, and plants have been commercially used for different applications. But because of their rapid growth rate, the limited space required for their cultivation, and the ease with which they can be genetically manipulated to generate new enzymes with altered properties that are desirable for the various applications, currently microorganisms are the major sources of commercially important proteases [2].

Proteases exhibit different properties in terms of substrate specificity, active site configuration, and catalytic mechanisms, response to $\mathrm{pH}$ and temperature for activity and stability. These differences offer great potential for a variety of biotechnological applications [3]. Today proteases find important application in the detergent, leather tanning, pharmaceutical, and food and feed processing industries [4].

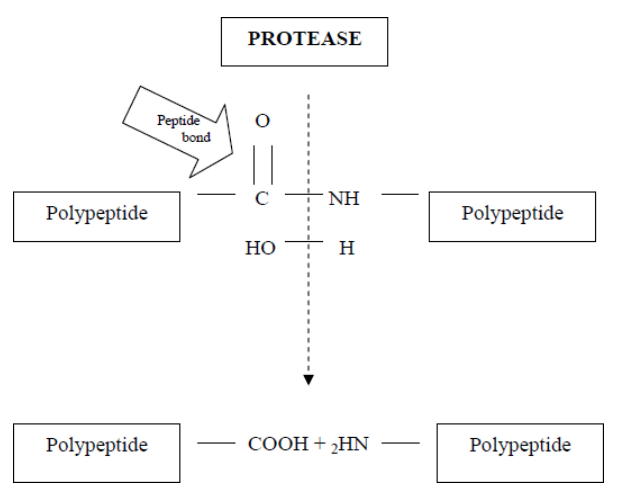

Figure 1. Protease catalysis of peptide bonds or proteolysis [1]. 
Proteases are classified into different groups based on their composition of amino acids in their active site or their $\mathrm{pH}$ optimum for activity. Based on their active center proteases are classified as serine (EC. 3.4.21), cysteine (thiol) (EC 3.4.22), aspartic (EC3.4.23) and metalloprotease (EC 3.4.24) [5]. Based on optimum $\mathrm{pH}$, proteases are divided as acidic, neutral, and alkaline. Due to their relatively high activity and stability at high $\mathrm{pH}$ alkaline proteases are the most commonly used industrial enzymes [6], their major use being as components of household laundry detergents [7]. This is because the $\mathrm{pH}$ of most laundry detergents is generally in the range of $\mathrm{pH} 9.0-12.0$.

Proteolytic enzymes added into detergents must have characteristics such as good stability and activity at relatively high temperature, broader specificity to be able to hydrolyze different proteins, active and stable at alkaline $\mathrm{pH}$ values, and stable in the presence of other detergent components like perfumes, surfactants, and bleaches. In addition, stability during storage and washing are also of desirable properties [8].

Before commercial detergents were available, most people in the highlands of Ethiopia used endod berry as a traditional detergent to wash cloths. Endod (Phytolacca dodecandra) is a plant, commonly known as the African soapberry plant. With the introduction of commercial detergents, the use of endod for laundry application is gradually forgotten. If the washing efficiency of endod is improved, there is still a possibility to use it as a green laundry detergent. One way to improve the washing efficiency of detergents is the addition of proteolytic enzymes. At present, more than $90 \%$ of the commercial detergents contain enzymes as washing supplements. Therefore, identifying proteolytic enzymes that are active and stable in the presence of endod, the washing to temperature and $\mathrm{pH}$ could lead to the development of an effective and ecofriendly endod based detergent. Alkaline proteases are highly used in detergent industry because they are used as cleaning additives in detergents to facilitate the release of proteins within a short period of time but a large number of alkaline proteases currently used for detergent applications have some limitations such as low activity and stability in the presence of chelating agents, surfactants, and bleaches [3] and also the components of detergent including surfactant and enzyme are imported from other countries. So, in this study, we focused on producing a stable alkaline protease enzyme and supplement it on endod as "green detergent" for use as a laundry detergent.

\section{Materials and Methods}

All chemicals used in the study were purchased from the local market and were of analytical grade.

\subsection{Media and Culture Conditions for Isolation, Screening and Enzyme Production}

In this study, all media preparations were accomplished by following the procedures developed by [9]. Soil samples were collected from $5-10 \mathrm{~cm}$ depth into plastic bags from Addis Ababa University and Mojo tannery from decomposing hair and used for the isolation of different microorganisms. Isolates were purified through repeated streaking and 56 isolates were used for screening for enzyme production.

The media used for isolation, screening, and enzyme production was composed of $\mathrm{g} / \mathrm{l}$ : casein 5 ; peptone 5 ; yeast extract 2; $\mathrm{NaCl} \mathrm{5;} \mathrm{MgSO}_{4} .7 \mathrm{H}_{2} \mathrm{O} 0.2 ; \mathrm{CaCl}_{2} 0.1 ; \mathrm{K}_{2} \mathrm{HPO}_{4} 1$; and $\mathrm{pH}$ at 10 . Sodium carbonate was separately autoclaved and added to the rest of the medium after cooling. A loopful of sample was streaked on casein-agar plates and incubated at $32^{\circ} \mathrm{C}$ for $48 \mathrm{~h}$. Enzyme production was carried out in 500 $\mathrm{ml}$ flasks containing $100 \mathrm{ml}$ medium. After $48 \mathrm{~h}$ incubation at $32^{\circ} \mathrm{C}$ with rotary shaking the culture was harvested and cells separated by centrifugation and the supernatant was used as the enzyme source for the assay procedure.

\subsection{Enzyme Assay}

The reaction mixture in a total volume of $500 \mu \mathrm{l}$ was composed of $1 \%$ casein in $50 \mathrm{mM}$ glycine $\mathrm{NaOH}$ buffer, $\mathrm{pH}$ 10 and $50 \mu \mathrm{l}$ of crude enzyme. After $30 \mathrm{~min}$ incubation at $60^{\circ} \mathrm{C}$, the reaction was terminated by adding $450 \mu \mathrm{l}$ of $10 \%$ trichloroacetic acid. After centrifugation at 10,000 rpm for $5 \mathrm{~min}, 150 \mu \mathrm{l}$ supernatant was taken and mixed with $750 \mu \mathrm{l}$ of $0.5 \mathrm{M}$ sodium carbonate followed by addition of $150 \mu \mathrm{l}$ $\mathrm{N}$ Folin-Ciocalteu"s phenol reagent. The reaction mixture was allowed to stand for $30 \mathrm{~min}$ at room temperature and absorbance measured at $660 \mathrm{~nm}$. One unit of protease activity was defined as the amount of the enzyme that released $1 \mu \mathrm{g}$ tyrosine per min under the conditions described above.

\subsection{Morphological and Biochemical Characterization of Isolate aau 2106}

Colony characterization such as configuration, margin, pigment, arrangement, and shape were investigated microscopically and direct observation of the $24 \mathrm{~h}$ old colony on the agar plate. Gram test was carried using the general procedure of gram test and $3 \% \mathrm{KOH}$. Biochemical characteristics such as catalase, casein, gelatin, and starch hydrolysis test were undertaken as follows. Catalase tests was investigated using $3 \% \mathrm{H}_{2} \mathrm{O}_{2}$ by dropping on the slide with $48 \mathrm{~h}$ at $32^{\circ} \mathrm{C}$ grown fresh colony and observing whether an air bubble was detected [11]. Casein hydrolysis test was examined on casein agar plate [9], starch hydrolysis test was examined on a starch medium, and gelatin hydrolysis test was examined in $12 \%$ gelatin and a loop full sample of isolate aau 2106 was incubated for $48 \mathrm{~h}$ and placed in the refrigerator for $20 \mathrm{~min}$ and see if the gelatin medium is hydrolyzed [12].

\section{Characterization of the Enzyme}

\subsection{Effect of $\mathrm{pH}$ on the Activity and Stability of Protease}

The activity of protease was measured at different $\mathrm{pH}$ 
values from 6.5 to 10.5 . The $\mathrm{pH}$ was adjusted using one of the following buffers (100mM): phosphate ( $\mathrm{pH}$ 6.0-8.0), Tris- $\mathrm{HCl}$ ( $\mathrm{pH} 7.5-9)$, glycine- $\mathrm{NaOH}(\mathrm{pH} 8.5-10.5)$ with a final concentration of $50 \mathrm{mM}$ in a reaction mixture. After incubation at $60^{\circ} \mathrm{C}$ the activity of protease was measured [9].

\subsection{Effect of Temperature on the Activity and Stability of Protease}

The activity of protease was measured at different temperature values from 40 up to $75^{\circ} \mathrm{C}$ and also the effect of calcium was measured by adding $5 \mathrm{mM} \mathrm{CaCl}_{2}$ into substrate $1 \%$ casein and the activity of protease was measured. The stability of protease was measured by incubating the enzyme at different time from 0 min up to 60 $\min$ at 55 and $60^{\circ} \mathrm{C}$ then the activity of protease was measured [9].

\section{Enzyme production Through Solid State Fermentation}

\subsection{Effect of Incubation Time on Protease}

To investigate the effect of incubation time on protease production flasks containing $10 \mathrm{~g}$ wheat bran with mineral salts $\left(\mathrm{NaCl} 0.5 \mathrm{~g}, \mathrm{CaCl}_{2} . \mathrm{H}_{2} \mathrm{O} 0.01 \mathrm{~g}, \mathrm{MgSO}_{4} .7 \mathrm{H}_{2} \mathrm{O} 0.02 \mathrm{~g}\right.$, $\mathrm{K}_{2} \mathrm{HPO}_{4} 1 \mathrm{~g}$ ) having 1:1.5 ratio of moisture content were incubated at $32^{\circ} \mathrm{C}$ from 24 to $120 \mathrm{~h}$. Enzyme extraction and the assay was carried out following the standard procedure.

\subsection{Effect of Moisture on the Production of Enzyme}

The effect of moisture for the production of protease was determined by incubating the culture media containing $10 \mathrm{~g}$ of wheat bran and mineral salts within the ratio of $1: 0.5$ to $1: 3$ at $32^{\circ} \mathrm{C}$ for $96 \mathrm{~h}$ followed by enzyme extraction by following the standard procedure. To optimize the extraction, process the residue was re-extracted up to three times and each extract was tested for enzyme activity separately. Those extracts having significant activity were pooled together and the activity measured from the pool.

\subsection{Effect of Nitrogen on the Production of Enzyme}

The activity of protease was measured by adding $0.5 \%$ (w/v) nitrogen sources: ammonium sulphate, sodium nitrate, yeast extract, peptone, and casein in a media containing $10 \mathrm{~g}$ wheat bran with mineral salts at the ratio of $1: 1$ for $96 \mathrm{~h}$ incubation period. Enzyme extraction and assay were carried out following the standard procedure.

\subsection{Concentration of Enzyme}

The enzyme was purified using $96 \%$ ethanol with in the ratio of $1: 3$ and it was precipitated at $-4^{\circ} \mathrm{C}$ for $1 \mathrm{~h}$. Then, the supernatant was discarded and the pellet was centrifuged at $10,000 \mathrm{rpm}$ and again the supernatant was discarded and the pellet was diluted with buffer.

\section{5. “Endod” Formulation as Detergent}

Endod berry was harvested from Addis Ababa University College of Natural Science around chemistry department and sun dried for 2 days followed by grinding using an electric grinder. A weighed amount of $60 \mathrm{~g}$ powdered endod was then added to an equal volume of $60 \mathrm{ml}$ water and set aside for 8 days. The endod was then extracted using $300 \mathrm{ml}$ methanol followed by removal of the solvent methanol through evaporation then formulated a detergent with other chemicals in g: $\mathrm{Na}_{2} \mathrm{HPO}_{4}$ 0.62; Citric acid 0.124; $\mathrm{Na}_{2} \mathrm{CO}_{3}$ 0.04; $\mathrm{NaHCO}_{3}$ 0.39; Endod 0.21.

\subsection{Effect of pH on the Detergency of Endod}

The effect of $\mathrm{pH}$ on the detergency of endod was investigated by observing the formation of foam and the time that the foam stayed by adjusting the $\mathrm{pH}$ of the formulated detergent using buffers (Tris-Hcl and Glycine) with $\mathrm{pH}$ values of $7.5,8,8.5,9,9.5$, and 10 .

\subsection{Stability of the Enzyme with Different Detergents and Endod}

Detergent solutions (Arial and Omo) at a concentration of $7 \mathrm{mg} / \mathrm{ml}$ were prepared separately in distilled water. The solutions were boiled for $30 \mathrm{~min}$ at $100^{\circ} \mathrm{C}$ to destroy any protease that already present in the detergents and cooled. Equal enzyme concentration was added to each detergent and endod solution and the mixture was incubated at $50^{\circ} \mathrm{C}$ for different time intervals from $0-120 \mathrm{~min}$. Then stability of the enzyme was then measured.

\subsection{Effect of Enzyme Concentration in Stain Removal}

Different concentration of enzyme was supplemented in endod and commercial detergent with different concentration amounts in U/g of 9.5, 19, 28.5, 38, 47.5, and 57 and wash a $24 \mathrm{~h}$ stained clothes by egg and blood from Kara slaughterhouse. And this was evaluated by 5 students to rank as 1- 4 depending upon the cleanness of the clothes in ascending order meaning the cleaner cloth will get the highest rank by comparing with the control (a cloth only washed by water).

\subsection{Wash Performance}

White clean cotton cloth piece $(4 \mathrm{~cm} \times 4 \mathrm{~cm})$ stained with $200 \mu \mathrm{l}$ blood and $400 \mu \mathrm{l} \mathrm{egg}$ and dried. Then after $24 \mathrm{~h}$ all the stained clothes were subjected to wash treatments with the only endod, commercial detergents (Arial and Omo), and also supplemented with $57 \mathrm{U} / \mathrm{g}$ enzyme, commercial detergents without enzyme (by boiling $7 \mathrm{mg} / \mathrm{ml}$ detergent at $100^{\circ} \mathrm{C}$ for $30 \mathrm{~min}$ and cooled) and also with only tap water and was taken as a control then the clothes were dried and visually examined by 5 students and took the average then converted it into a percentage. 


\subsection{Data Analysis}

All data presented here in this study was the average of two measurements and all graphical and numerical data values generated by using Microsoft Excel 2010 and Sigma Plot version 10 .

\section{Results}

\subsection{Isolation and Screening of Alkaline Protease Producing Bacteria}

Based on proteolytic activity, out of a total of 56 isolates tested, one isolate, designated as aau 2106, was selected for further study. The isolate showed high casein degradation within 3 days of incubation at $32^{\circ} \mathrm{C}$ (Figure 2).

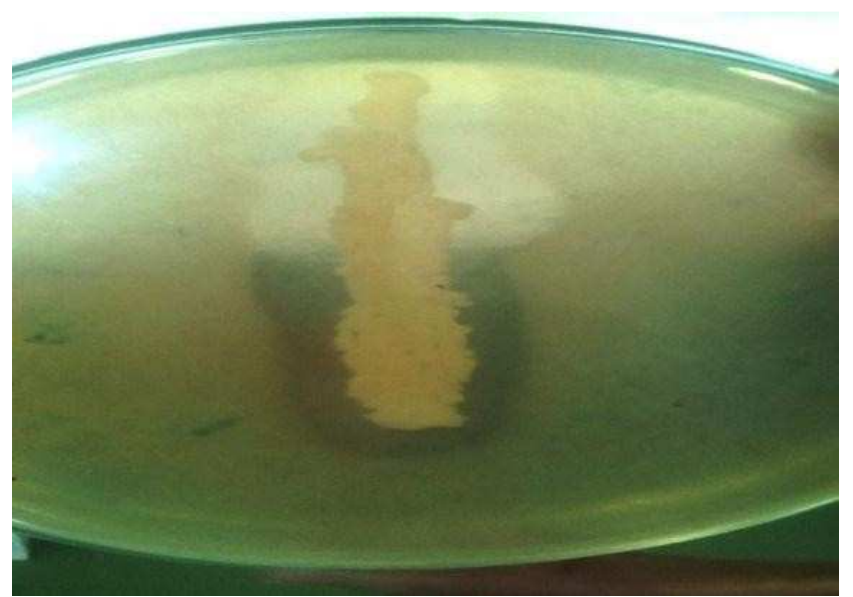

Figure 2. solate aau 2106 grown on a casein agar plate and the clear zone shows the presence of proteolytic activity.

Table 1. List of isolates and their activity on the casein agar plate.

\begin{tabular}{llll}
\hline No activity & Moderate activity & Good activity & Very good activity \\
\hline aau 1803, aau 1804, baau 1805 & aau 1802, aau 1809 & aau 1801, aau 1806 & aau 1908 \\
aau 1904, aau 1905, & aau 1901, aau 1907, & aau 1808, aau 1902 & aau 2003 \\
aau 2001, aau 2006, aau 2009 & aau 1909, aau 2002 & aau 1905, aau 1906 & aau 2008 \\
aau01, aau 02, aau 05, aau 07, & aau 2004, aau 2005, aau 2007 & aau 1903, aau 1807 & aau 2104 \\
aau 08, aau 09, aau 10, aau 12 & aau 2202, aau 2107, aau 2109 & aau 2101, aau 2108 & aau 2105 \\
aau 2201, aau 2203 & aau 04, aau 06 & aau 2103, aau 2102 & aau 2106, aau 03 \\
aau 2207, aau 11 & aau 2204, aau 2205, aau 2206 & & \\
\hline
\end{tabular}

aau, Addis Ababa University

\subsection{Characterization and Identification of Isolate aau 2106}

Table 2 shows results of morphological and biochemical tests of isolate aau 2106. Based on its morphological and physiological characteristics the isolate was characterized as gram positive and catalase positive. The colonies were characterized as chalky, circular configuration, hard, and white. It is rod shaped cell when observed under light microscope with 1000X magnification power. And it has the ability to hydrolyze casein and cannot hydrolyze starch and gelatin.

Table 2. Morphological identification and biochemical test of isolate no aau 2106.

\begin{tabular}{ll}
\hline Test on colony morphology & aau 2106 \\
\hline Configuration & Circular \\
Margin & Hard \\
Pigment & Chalky \\
Cell shape & Rod \\
Cell arrangement & Pairs \\
Gram test & Positive \\
Catalase test & Positive \\
Casein hydrolysis & Positive \\
Gelatin hydrolysis & Negative \\
Starch hydrolysis & Negative \\
\hline
\end{tabular}

\section{Characterization of Protease Enzyme}

\subsection{Effect of pH on the Activity of Protease}

The effect of $\mathrm{pH}$ on activity of the enzyme was determined from $\mathrm{pH}$ 6.0-10.5. The enzyme was active in a broad $\mathrm{pH}$ range with an optimum at $\mathrm{pH} 9.5$, and retained greater than $50 \%$ of its maximum activity in the $\mathrm{pH}$ range of $6.5-10.5$ (Figure 3 ). The enzyme lost $63.2 \%$ of its maximum activity under slightly acidic conditions (below pH 6.5). 


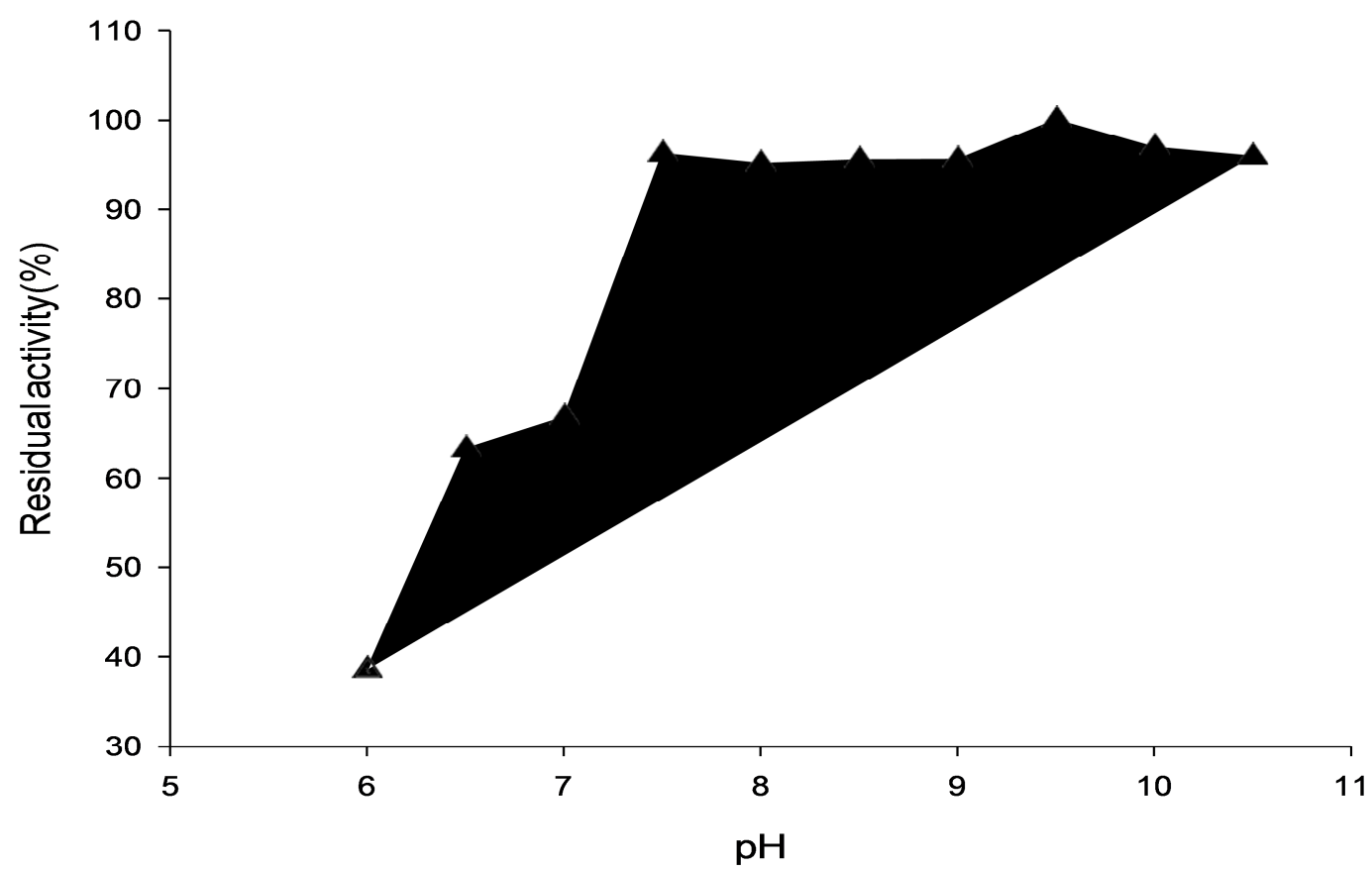

Figure 3. Effect of $p H$ on the activity of protease.

\subsection{Effect of Temperature on the Activity of Protease}

The effect of temperature on proteolytic activity of protease extracted from aau 2106 was determined in the temperature range of $40-75^{\circ} \mathrm{C}$. The enzyme showed higher activity in temperature range of $55-65^{\circ} \mathrm{C}$ with an optimum at $60^{\circ} \mathrm{C}$ (Figure 4) both in presence and absence of calcium.

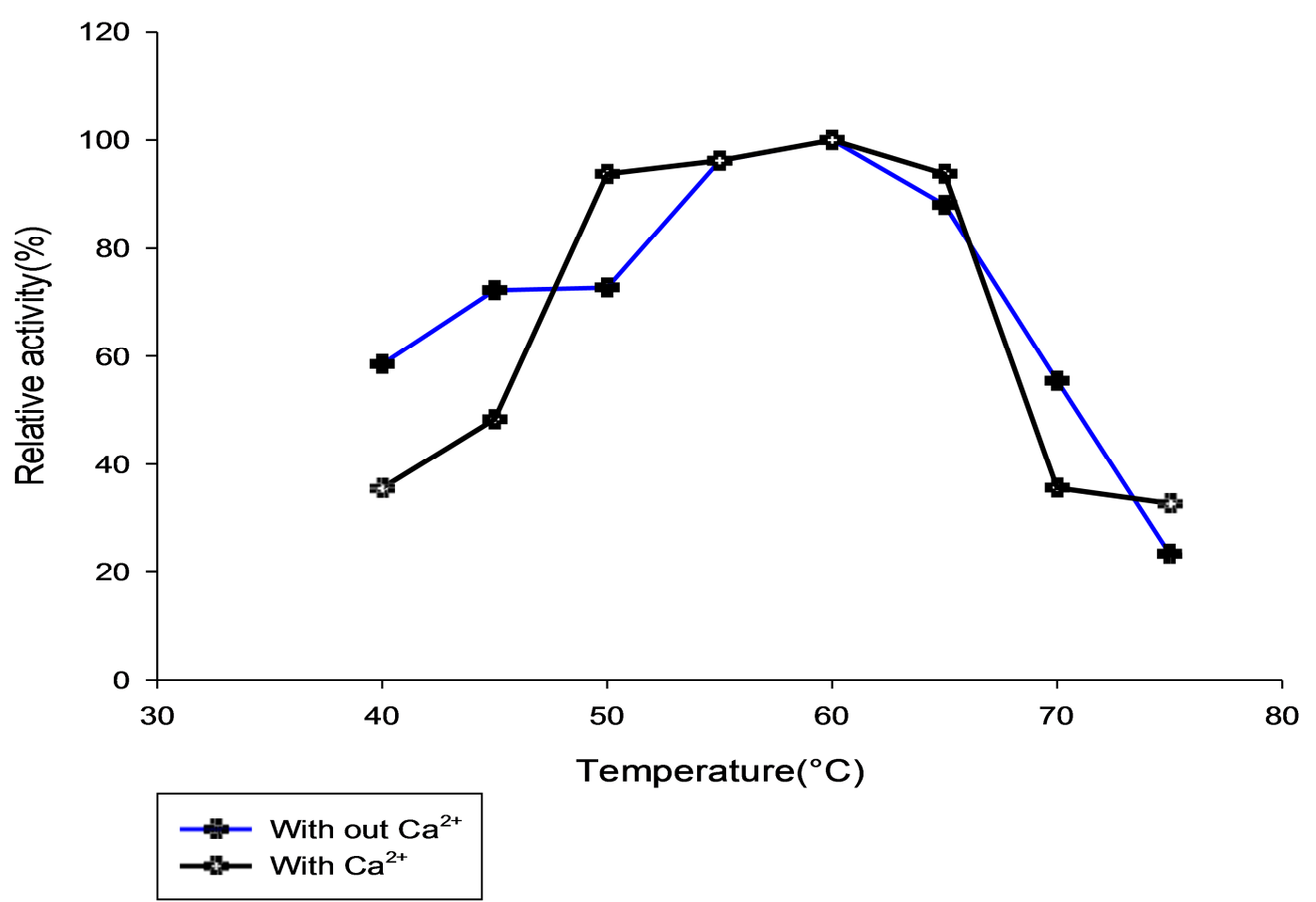

Figure 4. Effect of temperature on the activity of protease.

\subsection{Effect of Temperature on Stability of Protease}

The enzyme of aau 2106 retained more than $50 \%$ of its maximum activity after $10 \mathrm{~min}$ incubation in both temperature values $\left(55\right.$ and $\left.60^{\circ} \mathrm{C}\right)$ (Figure 5). 


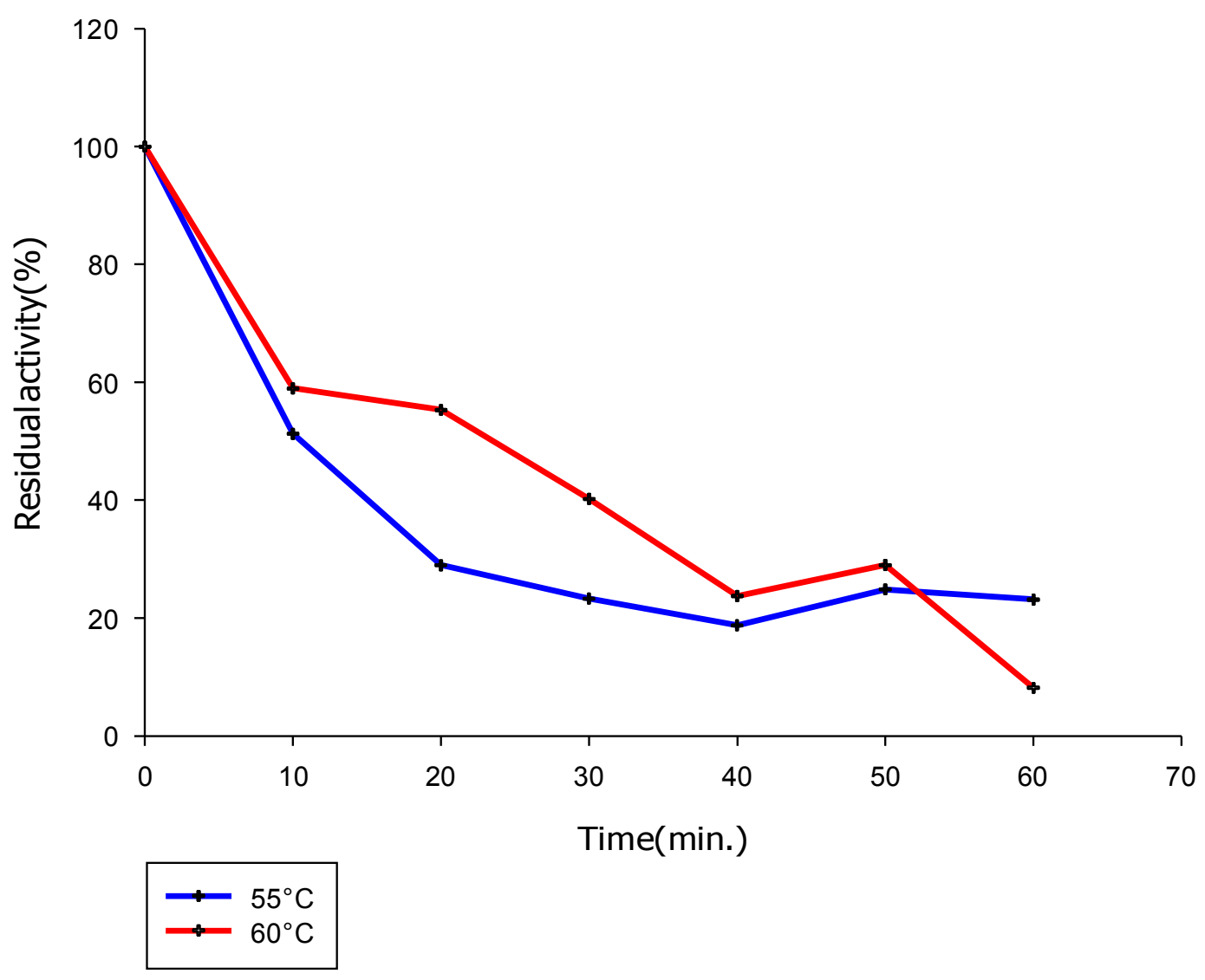

Figure 5. Effect of temperature stability on protease.

\subsection{Enzyme Production Through Solid State Fermentation}

Effect of Nitrogen Source on the Production of Protease

When enzyme production was tested in the presence of casein, peptone, yeast extract, ammonium sulphate, high activity was recorded in the presence of casein followed by peptone, and yeast extract (Figure 6).

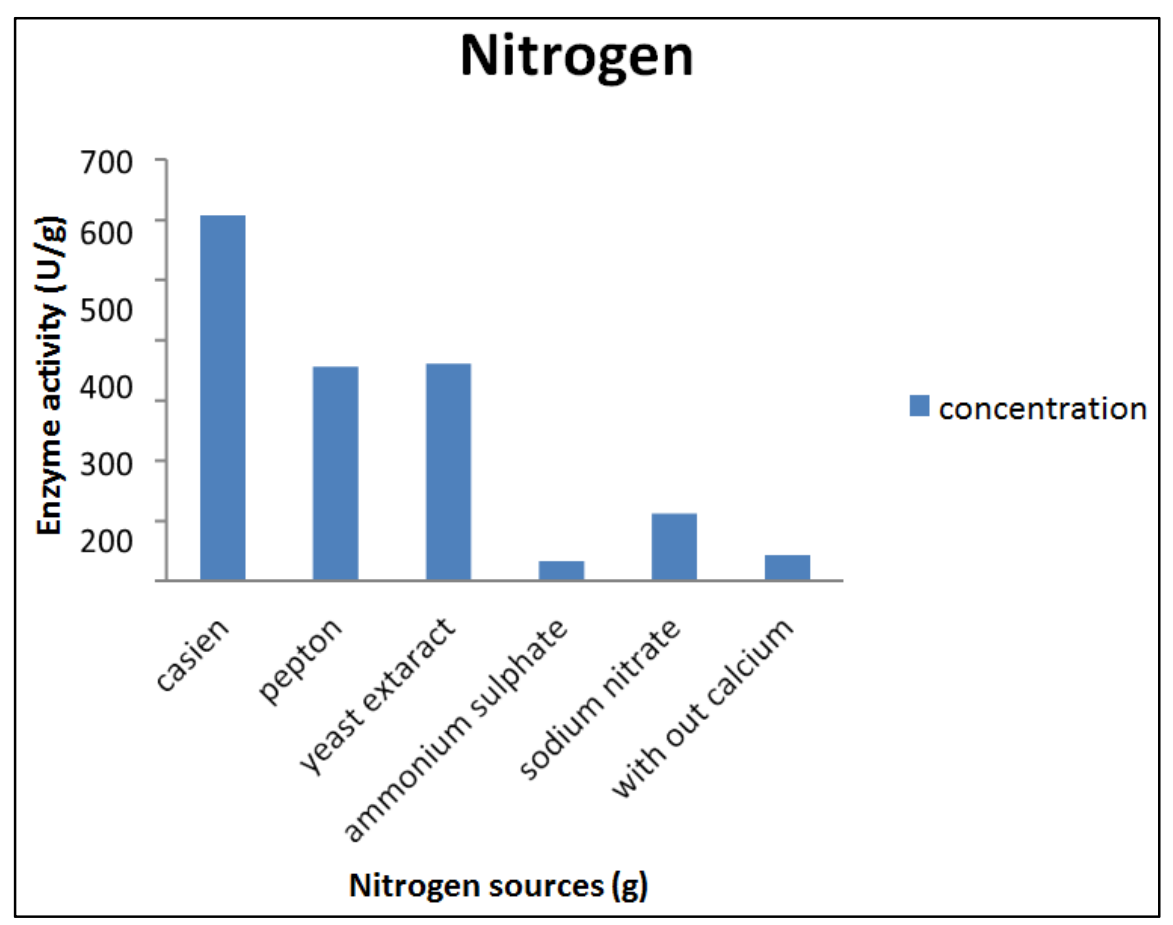

Figure 6. Effect of nitrogen on the crude protease aau 2106. 


\subsection{Effect of Moisture on the Enzyme Production}

When the organism is grown under solid state fermentation the highest protease activity was observed at moisture to solid tratio of 1:1. A moisture content above the optimum resulted in gradual decrease of enzyme activity (Figure 7).

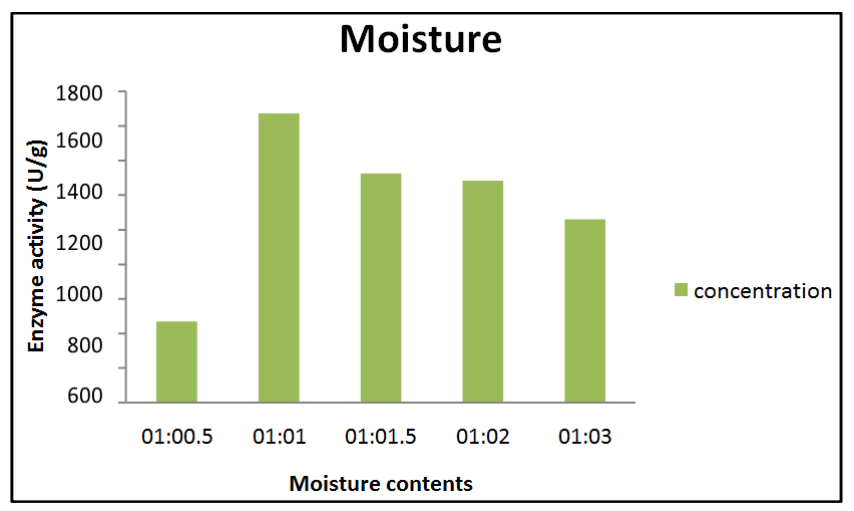

Figure 7. Effect of moisture on the enzyme activity.

\subsection{Effect of Incubation time on Enzyme Production}

The time course of protease production using solid-state fermentation was measured from 24-120h. Less enzyme production was observed from $24-48 \mathrm{~h}$. Then the production started to increase progressively from 72 up to $96 \mathrm{~h}$ and started to decrease at $120 \mathrm{~h}$ (Figure 8).

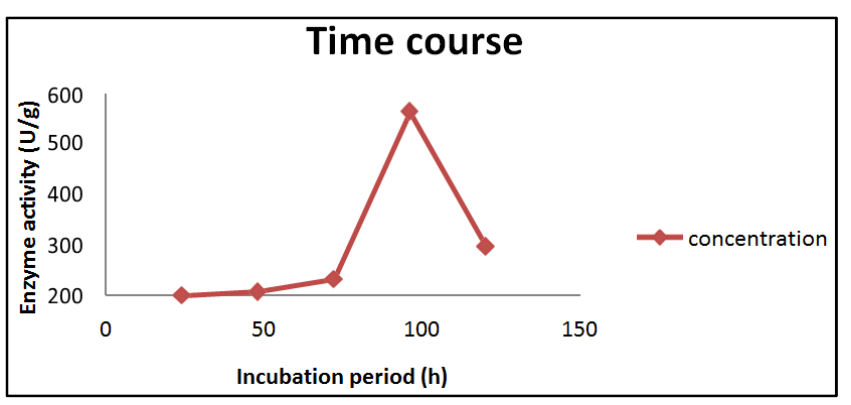

Figure 8. Effect of Time on the Production of Protease.

\subsection{Effect of pH on the Detergency of Endod}

The effect of $\mathrm{pH}$ on the detergency of endod was investigated and formation of foam was high in $\mathrm{pH}$ range from 7.5 up to 9 and at $\mathrm{pH} 8$ the highest foam formation was observed. And the time that the foam stayed was over $24 \mathrm{~h}$. The detergency decreased in $\mathrm{pH}$ values of 9.5 and 10 and it stayed only for about $30 \mathrm{~min}$.

\subsection{Enzyme Stability in the Presence of Endod and Commercial Detergents}

The stability of protease with commercial detergents (Omo, Arial) and endod was measured and the enzyme was stable in all detergents including endod and the enzyme showed higher stability on endod (Figure 9).

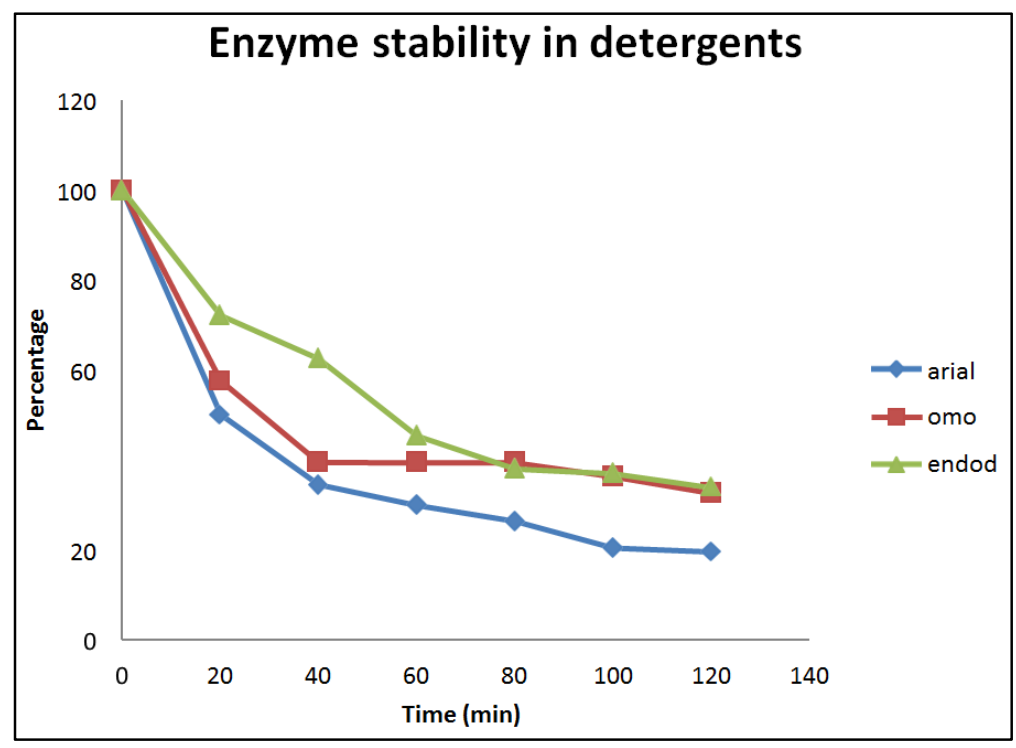

Figure 9. The stability of protease with commercial detergents and endod.

Table 3. Effect of enzyme concentration on stain removal efficiency.

\begin{tabular}{ll}
\hline Enzyme concentration (U/g) & Percentage (\%) \\
\hline 9.5 & 25 \\
19 & 45 \\
28.5 & 60 \\
38 & 70 \\
47.5 & 85 \\
57 & 100 \\
\hline
\end{tabular}

$\mathrm{U} / \mathrm{g}$, units per gram.

\subsection{Effect of Enzyme Concentration on Stain Removal Efficiency}

The concentration of enzyme has also an effect on the stain removal efficiency. More than 50\% stain removal efficiency was observed for enzyme concentrations ranging from $28.5-57 \mathrm{U} / \mathrm{g}$ with the highest stain removal activity at $57 \mathrm{U} / \mathrm{g}$. 


\subsection{Stain Removal Activity of Alkaline Protease}

Stain removal activity of protease was measured using cotton cloth that was stained with egg and blood. A sample containing protease showed high removal of stain. For example, in a cloth which is stained by egg have high stain removal activity on Arial supplemented with protease enzyme and in a cloth, which is stained by blood showed high activity on endod supplemented with protease.

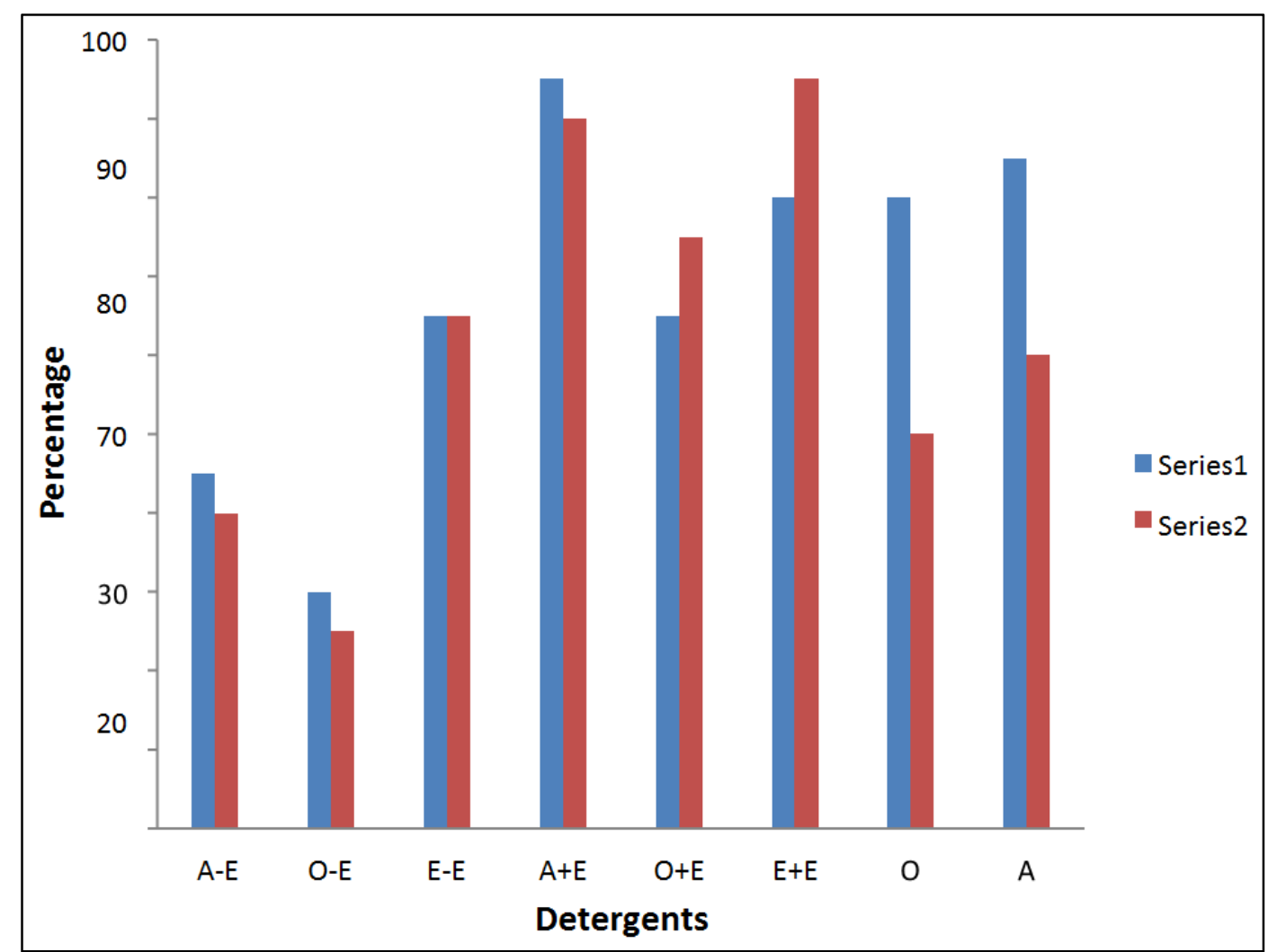

Figure 10. Stain removal activity of A-E-Arial without enzyme, $O-E-O m o$ without enzyme, E-E-Endod without enzyme, $A+E-$ Arial with enzyme, $O+E-$ Omo with enzyme, E+E-Endod with enzyme, O-Omo, A-arial, and on a cloth stained by egg (series 1) and blood (series 2).

High stain removal activity was observed when the commercial detergent Arial supplemented with enzyme from isolate aau 2106 was used for the washing of egg stained cloths. And endod plus enzyme from aau 2106 have high stain removal activity and Arial plus enzyme from aau 2106 and Omo without any enzyme showed low activity, Endod and the commercial detergents Arial and Omo showed relative result which is good.
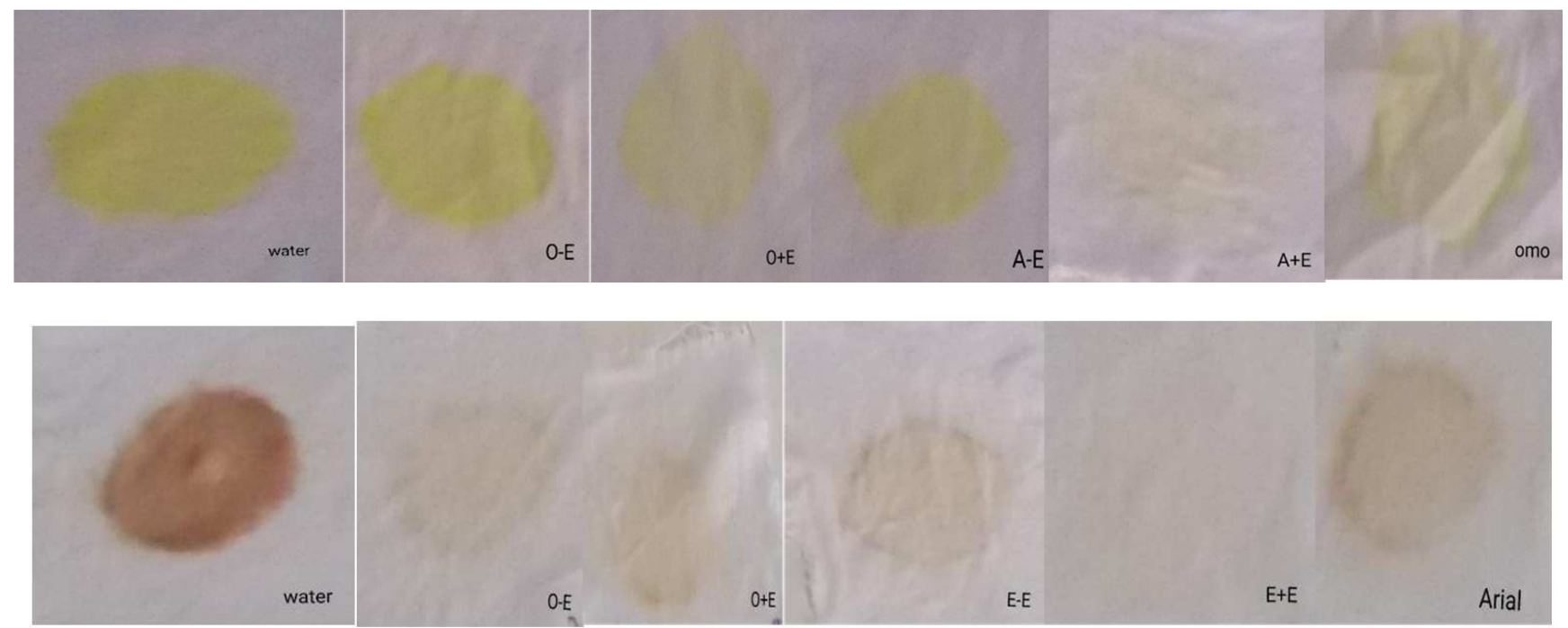

Figure 11. Wash performance checked on Egg yolk and blood stained clothes using commercial detergent and endod with and without enzyme; $C$ (O-E)- Omo without enzyme, $H(O)$ - Omo, $F(O+E)$ - Omo with enzyme, and $E(A+E)-$ Arial with enzyme; A-E- arial without enzyme, E-E-endod without enzyme, E+Eendod with enzyme, A-Arial. 


\section{Discussion}

The enzyme from isolate aau 2106 showed higher activity in the alkaline $\mathrm{pH}$ range 7-10.5 with an optimum $\mathrm{pH}$ at 9.510. The fact that it is optimally active in the alkaline range makes it an important enzyme for use in the detergent formulation [13]. This is because the $\mathrm{pH}$ of laundry detergents is generally in the range of 9.0-12.0.

Activity and stability in the normal laundry washing temperature range are considered important. Microbial alkaline proteases with optimum activity between $37-70^{\circ} \mathrm{C}$ have been reported by different researchers $[14,15]$. The protease reported in this study was active in the temperature range of $40-75^{\circ} \mathrm{C}$ with maximum activity observed at $60^{\circ} \mathrm{C}$. Two of the most important alkaline proteases of the detergent industry, subtilisin carberg produced by $B$. licheniformis and subtilisin Novo or bacterial protease Nagese (BPN), produced by $B$. amyloliquefaciens also showed higher activity at $60^{\circ} \mathrm{C}[8]$.

Calcium is needed for the stability of enzyme and proteases which are used as detergent additives are also using calcium to increase the enzyme stability [9]. The activity of the enzyme reported in this study increased in the presence of calcium. Similarly, the activity of alkaline protease from Aspergillus oryxea and Canidiobolus coronatus was increased in the presence of calcium [16].

Two researchers reported an addition of soya bean, casein, gelatin, peptone, yeast extract, tryptone, etc. in the growth medium as nitrogen sources results in high alkaline protease production $[17,18]$. In the current study, casein resulted high alkaline protease production. Similarly, Thomas et al. (2007), showed maximum protease production with casein from Virgibacillus pantothenticus and reported soya bean meal to be the highest for the optimal production of alkaline protease using Bacillus sp RJ14.

At a solid to moisture ratio of $1: 1$ higher enzymatic production was observed (Figure 7). Below and above the optimum enzyme production was reduced. For microbial growth under solid state fermentation the moisture content is known to have a huge impact on enzyme production. With increasing moisture content free water molecules occupy the inter-particle space of replacing air.

This thus leads to a decrease in the porosity of the medium, interfering with gas exchange. On the other hand a low amount of moisture decreases the diffusion of nutrients and metabolites [19].

Under solid-state fermentation maximum enzyme production by isolate aau 2106 was reached after $96 \mathrm{~h}$. Different organisms differ in the time course of their enzyme production. For example, isolates belonging to the genus Bacillus that produced high enzyme activity in the time range of $18 \mathrm{~h}$ to $96 \mathrm{~h}$ were reported $[17,20]$. Ideally, production in a short period could be preferred because it has a huge cost implication and also reduce the chance for spoilage by contaminants. But from large scale production point of view the time isolate aau 2106 took is not that short.
The use of protease as a supplement of endod and commercial detergents showed that the enzyme is stable in the detergent formulations indicating that it is resistant to surfactants, bleaching agent, and oxidizing agent that is present in each formula. This is very important property because bleach-stable enzymes are not generally available except for a few reports [21]. [22], reported enzymes which are supplemented into detergent formulations must be active and stable at high $\mathrm{pH}$ range (9-12) and high temperatures $\left(40-50^{\circ} \mathrm{C}\right)$. As shown in Figure 11, the enzyme which is supplemented in to Arial, Omo and endod removed the stain (blood and egg); higher removal of stain was observed at endod plus enzyme from isolate aau 2106.

The stain removal was done mechanically without any incubation with a minimum enzyme concentration $57 \mathrm{U} / \mathrm{g}$. [23], reported the protease that was used to remove egg yolk stain from test fabric needs $2 \mathrm{~h}$ for complete egg stain removal even at $40^{\circ} \mathrm{C}$. The removal of stains even at room temperature with a minimum concentration of enzyme implies that this study was highly cost-effective and needs less amount of enzyme supplementation during detergent formulation.

\section{Conclusion and Recommendation}

The alkaline protease produced by isolate aau 2106 has a very good potential to be used as a detergent additive supplementing endod. When used with endod it was very efficient for stain removal. The enzyme was also stable in the presence of endod. This shows enzyme supplementation of endod could allow the development of an ecofriendly detergent formulation.

The organism that produces the enzyme was able to grow under solid state fermentation using wheat bran as substrate and this help to reduce the production cost of the enzyme which makes the process highly economical.

However, detailed biochemical and biophysical characterization of the enzyme is not yet carried out. Therefore, it is recommended that:

1. The enzyme is purified and characterized in detail to have a better understanding of its biochemical and biophysical properties

2. The gene coding for the enzyme is cloned and some of the properties be modified to through protein engineering.

\section{List of Abbreviation}
AAU: Addis Ababa University
H: Hour
SSF: Solid state fermentation

\section{References}

[1] Sookkheo, B., Sinchaikul, S., Phutrakul, S. and Chen, S. T. (2000). Purification and characterization of the highly thermostable proteases from Bacillus stearothermophilus TLS33. Protein Expression and Purification. pp. 20 (2): 142-151. 
[2] Kocher, G. S. and Mishra, S. (2009). Immobilization of Bacillus circulans MTCC 7906 for enhanced production of alkaline protease under batch and packed bed fermentation conditions. Internet Journal of Microbiology. pp. 7: 2.

[3] Gupta, R., Beg, Q. K., Lorenz, P. (2002). Bacterial alkaline proteases: molecular approaches and industrial applications. Applied microbiology and biotechnology. pp. 59: 13-32.

[4] Amare Gessesse (1997). The use of nug meal as low-cost substrate for the production of alkaline protease by the alkaliphilic Bacillus sp. AR-009 and some properties of the enzyme. Bioresource Technology. pp. 62: 59-61.

[5] Chu, W. H. (2007). Optimization of extracellular alkaline protease production from species of Bacillus. Journal of industrial microbiology and biotechnology. pp. 34: 241-245.

[6] Guleria, A. and Chandna, S. (2016). ATM kinase: Much more than a DNA damage responsive protein. DNA repair. pp. 39: $1-20$.

[7] Nehra, K. S., Dhillon, S., Chaudhary, K. and Singh, R. (2002). Production of alkaline protease by Aspergillus species under submerged and solid state fermentation. Indian. Jornal of Microbiology. pp. 42: 43-47.

[8] Horikoshi, K. (1990). Enzymes of alkalophiles. Microbial Enzyme and Biotechnology. pp. 2: 275-294.

[9] Amare Gessesse and Birhanu Abegaz Gashe (1997). Production of alkaline protease by an alkaliphilic bacterium isolated from an alkaline soda lake. Biotechnology letters. pp. 19 (5): 479.

[10] Shimogaki, H., Takeuchi, K., Nishino, T., Ohdera, M., Kudo, T., Ohba, K. and Irie, M. (1991). Purification and properties of a novel surface-active agent-and alkaline-resistant protease from Bacillus sp. Y. Agricultural and biological chemistry. pp. 55 (9): 2251-2258.

[11] Muhammed, S. (2011). Production, characterization, and potential application of a keratinolytic alkaline protease produced by alkaliphilic Vibrio sp.

[12] Leboffe, M. J. and Pierce, B. E. (2010). Microbiology: laboratory theory and application. Morten Pubishing Company.

[13] Kalisz, H. M. (1988). Microbial proteinases. Advance in Biochemical Engineering/Biotechnology. pp. 36: 1-65.
[14] El-Sawah, M. M. A. and El-Din, M. Z. (2000). Production and properties of thermostable alkaline protease from Bacillus licheniformis and its importance in Domiati cheese ripening. Annals of Agricultural Science. pp. 45 (1): 113-127.

[15] Eftekhar, F., Fouladi, J. and Faghihi, M. (2003). Isolation and identification of an alkaline protease producing Bacillus from soil. Iranian journal of biotechnology. pp. 1: 183-185.

[16] Bhosale, H. S., Rao, B. M., Deshpande, V V. and Srinivasan, C. V. (1995). Thermostability of high-activity alkaline protease from candiobolus coronatus. Enzyme and microbial technology. pp. 17 (2): 136-139.

[17] Banerjee, U. C., Sani, R. K., Azmi, W., and Soni, R. (1999). Thermostable alkaline protease from Bacillus brevis and its characterization as laundry detergent additive. Process Biochemistry. pp. 35: 213-19.

[18] Hameed, A., Keshavarz, T. and Evans, C. S. (1999). Effect of dissolved oxygen tension and $\mathrm{pH}$ on the production of extracellular protease from a new isolate of Bacillus subtilisK2 for use in leather processing. Chemical Technology and Biotechnology. pp. 74: 5-8.

[19] Ellaiah, P., Adinarayana, K., Bhavani, Y., Padmaja, P. and Srinivasulu B. (2002). Optimization of process parameters for glucoamylase production under solid state fermentation by a newly isolated Aspergillus species. Process biochemistry. pp. 8: 615-20.

[20] Singh, J., Batra, N. and Sobti, R. C. (2001). Serine alkaline protease from a newly isolated Bacillus sp. SRR1. Process Biochemistry. pp. 36: 781-85.

[21] Tsuchiya, K., Nakamura, Y., Sakashita, H. and Kimura, T. (1992). Purification and characterization of a thermostable alkaline protease from alkalophilic Thermoactinomyces $\mathrm{sp}$. HS682. Bioscience, biotechnology, and biochemistry. pp. 56 (2): 246-250.

[22] Oberoi, Ruchi., Beg, Qasim., Puri, Sumant., Saxena, R., Gupta, Rani. (2001). Characterization and wash performance of an SDS-stable alkaline protease from Bacillus sp. World Journal of Microbiology and Biotechnology. pp. 17: 493-497.

[23] Kumar, D. and Bhalla, T. C. (2004). Purification and characterization of a small size protease from Bacillus sp. APR-4. National Institute of science communication and information resources. pp. 42 (5): 515-521. 